doi: $10.2306 /$ scienceasia1513-1874.2012.38.331

\title{
Accumulation pattern of heavy metals in marine organisms collected from a coal burning power plant area of Malacca Strait
}

\author{
Lubna Alam ${ }^{\mathrm{a}, *}$, Che Abd. Rahim Mohamed ${ }^{\mathrm{b}}$, Mazlin Bin Mokhtar ${ }^{\mathrm{a}}$ \\ a Institute for Environment and Development (LESTARI), University Kebangsaan Malaysia, Bangi, 43600, \\ Selangor \\ b Faculty of Science and Technology, University Kebangsaan Malaysia, Bangi, 43600, Selangor \\ ${ }^{*}$ Corresponding author, e-mail: lubna_762120@yahoo.com
}

Received 24 Apr 2012

Accepted 31 Aug 2012

\begin{abstract}
Nowadays, the marine environment is becoming vulnerable because of anthropogenic pollutants such as heavy metals carried by small particles of fly ash generated by coal burning power plants. Toxic heavy metals such as $\mathrm{Cd}, \mathrm{Cu}, \mathrm{Zn}, \mathrm{Pb}$, and $\mathrm{Cr}$ were estimated in three types of marine organisms, i.e., Arius maculatus, Penaeus merguiensis, and Anadara granosa, collected from a coal burning power plant area of Malaysia. An independent-sample $t$-test was conducted to compare the metal concentration in analysed species where significant differences were observed between A. maculatus, $P$. merguiensis, and A. granosa in the case of $\mathrm{Cd}, \mathrm{Cu}$, and $\mathrm{Cr}$ concentrations. Moreover, there were statistically significant difference between A. maculatus and A. granosa, as well as between P. merguiensis and A. granosa, in the case of $\mathrm{Zn}$ concentration. Similarly, A. maculatus and $P$. merguiensis, and A. maculatus and $P$. merguiensis demonstrated significant differences in the case of $\mathrm{Pb}$ concentration. Nevertheless, most of the species examined during this study exhibited concentrations that were lower than the permitted guideline. The hierarchical cluster analysis revealed two groups of analysed species where the first group included fish (A. maculatus) and shrimp (P. merguiensis), whilst the second group consisted of cockles (A. granosa). The calculated values of biota-sediment accumulation factor were 0.79, 0.22, 0.59, 0.07, and 0.06 for A. maculatus; 0.62, 2.31, 0.64, 0.05, and 0,04 for P. merguiensis; 5.10, 0.66, 0.79, 0.05, and 0.10 for $P$. merguiensis in the case of $\mathrm{Cd}, \mathrm{Cu}, \mathrm{Zn}, \mathrm{Pb}$, and $\mathrm{Cr}$, respectively. The patterns of biota sediment accumulation factor (BSAF) were $\mathrm{Cd}>\mathrm{Zn}>\mathrm{Cu}>\mathrm{Pb}>\mathrm{Cr}$ for A. maculatus, $\mathrm{Cu}>\mathrm{Zn}>\mathrm{Cd}>\mathrm{Pb}>\mathrm{Cr}$ for P. merguiensis, and $\mathrm{Cd}>\mathrm{Zn}>\mathrm{Cu}>\mathrm{Cr}>\mathrm{Pb}$ for A. granosa. However, the BSAFs revealed a higher accumulation ability of heavy metals in A. granosa. Therefore, this species can be used as a bio-indicator of marine pollution.
\end{abstract}

KEYWORDS: BSAF, cadmium, copper, zinc, lead, chromium

\section{INTRODUCTION}

Increasing trends of human population and coastal development contribute to the increase in anthropogenic pollution load, which has become a major threat to marine and aquatic habitats. Large amounts of heavy metals can be deposited in the aquatic system near the coal burning power plant area, as the smallest particles of fly ash are enriched with heavy metals ${ }^{1}$ and this holds ecological importance because of their toxicity, persistence, and bio-accumulation. As a result, there has been a growing interest in determining the heavy metal levels in marine environment and attention has been drawn to the measurement of contamination levels in public food supplies, particularly fish $^{2-4}$. Elevated amounts of metal concentrations in the southern areas and near power stations indicate the impact of coal-fired power stations on the lake. Aquatic organisms inhabiting sites polluted by coal ash are at risk because they accumulate extremely high concentrations of teratogenic trace elements, such as $\mathrm{Cd}, \mathrm{Cu}$, and $\mathrm{Se}$, in their tissues. Previous studies suggested that coal combustion byproducts can disrupt the biology of amphibians ${ }^{5}$.

Additionally, heavy metal concentrations in aquatic organisms along with bio-concentration have been extensively studied in various places around the world ${ }^{6-12}$. Attention has been given to the organism ability to reflect the environmental levels of trace metal contaminants in marine and estuarine ecosystems ${ }^{13}$. Since marine organisms accumulate contaminants from the environment, they have been used in marine pollution monitoring programmes. Heavy metal studies in aquatic biota indicate that 


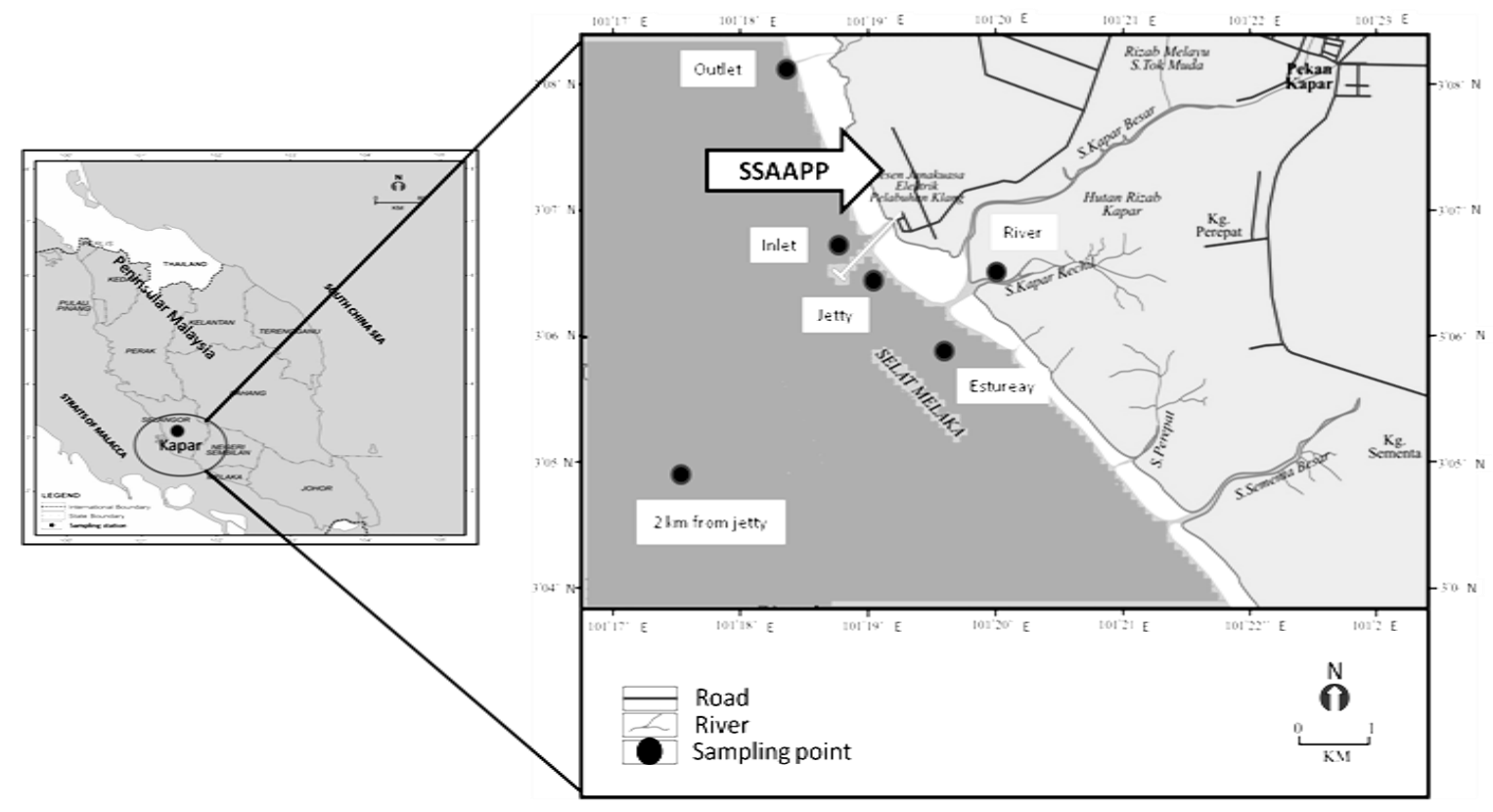

Fig. 1 Sampling locations at Kapar coastal area near the Sultan Salahuddin Abdul Aziz power plant.

heavy metals in aquatic organisms could be a more reliable water-quality indicator than chemical analysis of water column and sediment ${ }^{7,14}$. Bivalve molluscs, which are sedimentary, widespread, and have a long life span, have been well established as a bio-indicator for monitoring the concentration of heavy metals in many areas of the world. Similarly, fish is a good bioindicator because it is easy to be obtained in a large quantity, has a potential to accumulate metals, has a long lifespan, has an optimum size for analysis, and is easy to be sampled ${ }^{15}$. Studies regarding the heavy metal accumulation in crustaceans are scant.

As there is very little information regarding heavy metal behaviour around the coal burning power plant areas, particularly with respect to accumulation in marine organisms, this study aims to determine the concentrations of toxic heavy metals $(\mathrm{Cd}, \mathrm{Cu}, \mathrm{Zn}$, $\mathrm{Pb}$, and $\mathrm{Cr}$ ) in the edible portion of fish, crustaceans, and molluscs, collected from the local fish market of Kapar coastal area of Malaysia, which is adjacent to a coal burning power station.

\section{MATERIALS AND METHODS}

Samplings were carried out around the Sultan Salahuddin Abdul Aziz power station, which is located at the western coast line of west Malaysia, at the Malacca Strait. It is the largest power station in Malaysia with a generating capacity of $2420 \mathrm{MW}$ contributing about $23 \%$ of the country energy de- mand. Sediment samples were collected from six stations along the coastal area (Fig. 1) and organism samples were purchased from the local fish market of the village Tok Muda in August 2008, December 2008, and February 2009. A total of 15 samples for each organism were collected during every sampling period and the catch locations were verified with the fishermen.

The organism and sediment samples were transported to the laboratory and preserved in a freezer for further analysis. The organism samples were dissected to obtain the edible parts (muscle). The organisms and sediment samples were oven dried at $60^{\circ} \mathrm{C}$. After drying, the sediment sample was ground using mortars (Gelman No. 4012). Then, the sediment samples in the form of powder were sieved using a $200 \mu \mathrm{m}$ diameter sized sieve (Retsch). Three replicates of organisms and sediment samples were analysed to measure heavy metals such as $\mathrm{Cu}, \mathrm{Cd}$, $\mathrm{Zn}, \mathrm{Pb}$, and $\mathrm{Cr}$. All the glasswares used for analysis were acid washed to avoid possible contamination. About $0.3-0.5 \mathrm{~g}$ of dried samples for each replica were weighted in a beaker using electronic scales. The samples were then digested with a mixture of $30 \mathrm{ml}$ nitric acid $\left(\mathrm{HNO}_{3}, \mathrm{GR}, 65 \%\right.$, Merck) and $5 \mathrm{ml}$ of concentrated perchloric acid $\left(\mathrm{HClO}_{4}, \mathrm{GF}\right.$, $70 \%$, Merck). After that, $10 \mathrm{ml}$ of concentrated hydrochloric acid ( $\mathrm{HCl}, \mathrm{GR}, 37 \%$, Merck) was added to the samples and heated until dry. After cooling 
Table 1 Analytical result for the reference materials IAEA 407 (fish) and NIST 1646a (estuarine sediment) along with the certified value for each metal ( $\mu \mathrm{g} / \mathrm{g}$ dry weight of fish).

\begin{tabular}{llrrrrrrr}
\hline Elements & \multicolumn{1}{c}{ SRM } & \multicolumn{3}{c}{ Analysis } & Certified & $\begin{array}{c}\text { Mean re- } \\
\text { covery (\%) }\end{array}$ \\
\cline { 3 - 7 } & & Rep-1 & Rep-2 & Rep-3 & Rep-4 & Mean & value & can \\
\hline $\mathrm{Cd}$ & IAEA 407 & 0.15 & 0.15 & 0.18 & 0.14 & $0.16 \pm 0.02$ & 0.19 & 82.34 \\
& NIST 1646a & 0.10 & 0.11 & 0.17 & 0.12 & $0.12 \pm 0.03$ & 0.15 & 83.03 \\
$\mathrm{Cu}$ & IAEA 407 & 2.91 & 2.82 & 3.06 & 2.88 & $2.92 \pm 0.10$ & 3.28 & 88.89 \\
& NIST 1646a & 7.34 & 7.27 & 8.56 & 7.54 & $7.68 \pm 0.60$ & 10.01 & 76.69 \\
$\mathrm{Zn}$ & IAEA 407 & 54.35 & 59.48 & 57.83 & 50.48 & $55.5 \pm 4.0$ & 67.10 & 82.77 \\
& NIST 1646a & 34.24 & 35.43 & 57.21 & 37.95 & $41 \pm 11$ & 48.90 & 84.27 \\
$\mathrm{~Pb}$ & IAEA 407 & 0.11 & 0.11 & 0.11 & 0.09 & $0.10 \pm 0.01$ & 0.12 & 85.75 \\
& NIST 1646a & 8.82 & 8.67 & 11.11 & 8.85 & $9.4 \pm 1.2$ & 11.70 & 80.02 \\
$\mathrm{Cr}$ & IAEA 407 & 0.67 & 0.62 & 0.58 & 0.50 & $0.59 \pm 0.07$ & 0.73 & 81.29 \\
& NIST 1646a & 33.31 & 33.86 & 33.65 & 33.29 & $33.53 \pm 0.27$ & 40.90 & 81.98 \\
\hline
\end{tabular}

the sample, $2.5 \mathrm{ml}$ of $\mathrm{HNO}_{3}$ was added into the samples. A total of $20 \mathrm{ml}$ of de-ionized distilled water was added into the beaker containing the sample and filtered through a filter paper (Whatman, GF/C; diameter $47 \mathrm{~mm}$; pore size $0.45 \mu \mathrm{m}$ ). Subsequently, the filtered solutions were added with de-ionized distilled water up until $70 \mathrm{ml}$ to make it into $0.5 \mathrm{M} \mathrm{HNO}_{3}$. Determination of heavy metals was carried out using the inductively coupled plasma mass spectrometry (Perkin Elmer-Elan 9000). In order to confirm the validation of the method, SRM-407 provided by the International Atomic Energy Agency, was used for fish samples and SRM-1646a for estuarine sediment supplied by the National Institute of Standards and Technology was used for sediment analysis. The analytical results for the investigated heavy metals in the reference material were within or near the certified values (Table 1). Therefore, the recoveries of all the metals were satisfactory. Independent samples $t$-test was performed using the analytical software SPSS to compare the accumulation pattern of heavy metal in marine organisms. The following equation was used to calculate the biota-sediment accumulation factor ${ }^{16}$ :

$$
\mathrm{BSAF}=C_{\text {org }}(\text { dry weight }) / C_{\text {sed }}(\text { dry weight }),
$$

where $C_{\text {org }}$ is the concentration of heavy metal in organism and $C_{\text {sed }}$ is the concentration of heavy metal in sediment.

\section{RESULTS AND DISCUSSION}

The concentrations of analysed toxic metals in marine organisms during different sampling periods are presented in Fig. 2. An independent $t$-test was conducted to compare the concentration of cadmium in Arius maculatus and Penaeus merguiensis where a significant difference was observed $(t(88)=2.01$, $p=0.04)$. Similarly, significant differences were discovered in the case of A. maculatus and Anadara granosa $(t(45)=11.38, p=0.00)$, as well as $P$. merguiensis and A. granosa $(t(46)=11.80, p=$ $0.00)$. However, A. granosa $(1.48 \pm 0.55 \mu \mathrm{g} / \mathrm{g}$ dry wt) had the highest concentration of cadmium, followed by $A$. maculatus $(0.23 \pm 0.09 \mu \mathrm{g} / \mathrm{g}$ dry wt) and $P$. merguiensis $\left(0.18 \pm 0.11 \mu \mathrm{g} / \mathrm{g}\right.$ dry wt). Phillips ${ }^{17}$ also reported a higher amount of cadmium in molluscs. None of the species analysed in this study were found to contain cadmium concentration above the proposed permitted concentration and the values were within the range of other reported values ${ }^{12,17-43}$ (Table 2). A high concentration of cadmium causes several health problems to humans. Cadmium and its compound along with mercury and some other dangerous metals are included in the blacklist. Ingestion of cadmium produces shock acute renal failure when the amount exceeds $350 \mathrm{mg}^{44}$.

Mean copper concentration was highest in $P$. merguiensis $(21.6 \pm 7.8 \mu \mathrm{g} / \mathrm{g}$ dry wt), followed by $A$. granosa $(6.1 \pm 4.2 \mu \mathrm{g} / \mathrm{g}$ dry wt) and A. maculatus $(2.01 \pm 0.57 \mu \mathrm{g} / \mathrm{g}$ dry wt). There were significant differences between $A$. maculatus and $P$. merguiensis $(t(44.35)=12.51, p=0.00)$, A. maculatus and A. $\operatorname{granosa}(t(46.49)=6.88, p=0.00)$, and P. merguiensis and A. granosa $(t(56.23)=9.27$, $p=0.00)$. Barwick and Maher ${ }^{45}$ observed comparatively lower copper concentration in fish than the crustaceans and molluscs which support the present study. Copper concentrations measured in organisms are compared with the reported values of other places and the guideline (Table 2). The calculated values are within the range of previous studies and lower than the guidelines. The higher copper concentration found in $P$. merguiensis and A. granosa probably reflects active accumulation of copper by these species 
Table 2 Comparison of heavy metal contents ( $\mu \mathrm{g} / \mathrm{g}$ wet wt) in organisms samples with the guidelines and other studies.

\begin{tabular}{|c|c|c|c|c|c|c|c|}
\hline Species & Standard/Place & $\mathrm{Cd}$ & $\mathrm{Cu}$ & $\mathrm{Zn}$ & $\mathrm{Pb}$ & $\mathrm{Cr}$ & Reference \\
\hline \multirow[t]{16}{*}{ Fish } & USEPA limits & 2 & 120 & $120^{*}$ & 4 & 8 & Refs. $18,19^{*}$ \\
\hline & WHO & 1 & 30 & 100 & 2 & 50 & Ref. 20 \\
\hline & Food standard of Malaysia & 1 & 30 & 100 & 2 & & Ref. 21 \\
\hline & Caspian Sea & 0.0032 & 1.65 & 20.656 & 0.0144 & 0.35 & Ref. 22 \\
\hline & China & $0.01-0.04$ & $0.06-0.16$ & $2.39-4.49$ & & & Ref. 23 \\
\hline & Bahrain & 0.03 & & & 0.13 & & Ref. 24 \\
\hline & Yugoslovakia & $0.01-0.84$ & & & $0.02-1.7$ & & Ref. 25 \\
\hline & Barent Sea & $<0.01$ & 0.6 & $5.6-7.8$ & $<0.1$ & & Ref. 26 \\
\hline & Mumbai, India & 0.02 & 0.31 & 8.36 & 0.08 & 0.78 & Ref. 27 \\
\hline & Afyon, Turkey & 0.01 & $0.33-0.6$ & $6.73-10.74$ & 0.02 & & Ref. 28 \\
\hline & China & $0.004-0.021$ & $0.228-1.89$ & $16-130$ & $0.177-0.289$ & & Ref. 29 \\
\hline & Pahang, Malaysia & $0.15-0.47$ & $0.13-0.77$ & $1.69-6.76$ & $0.00-1.14$ & & Ref. 30 \\
\hline & Peninsular Malaysia & 2.4 & 3.8 & 58.4 & & & Ref. 31 \\
\hline & Langkawee, Malaysia & 0.9 & 0.01 & 49.39 & 1.1 & & Ref. 32 \\
\hline & India & 0.17 & 3.27 & 8.74 & 0.37 & 0.68 & Ref. 12 \\
\hline & Malaysia & 0.14 & 1.21 & 41.84 & 1.50 & 0.55 & Present study \\
\hline \multirow[t]{11}{*}{ Crustacean } & WHO & 2 & 10 & 1000 & 2 & & Ref. 32 \\
\hline & WHO & 0.2 & 10 & 1000 & & & Ref. 22 \\
\hline & India & 0.095 & 8.19 & 17.76 & 0.50 & 0.61 & Ref. 12 \\
\hline & Ghana & & 4.81 & 15.7 & 0.29 & & Ref. 33 \\
\hline & Senegal & 0.1 & 4.68 & 13.9 & 0.5 & & Ref. 34 \\
\hline & Cote d'Ivoire & 0.25 & 6.02 & 17.94 & & & Ref. 35 \\
\hline & Cameroon & 0.27 & 4.85 & 24.5 & & & Ref. 36 \\
\hline & Sabah, Malaysia & $1.6-6.1$ & $12.8-159$ & & $4.6-32$ & & Ref. 37 \\
\hline & Malaysia & $0.2-49.0$ & $32-99$ & 68.19 & $1.68-54$ & & Ref. 38 \\
\hline & Malaysia & $0.1-0.8$ & $0.8-24$ & $5.0-16.0$ & $0.1-5.9$ & & Ref. 39 \\
\hline & Malaysia & 0.10 & 12.06 & 42.41 & 1.00 & 0.29 & Present study \\
\hline \multirow[t]{8}{*}{ Mollusc } & Food standard of Malaysia & 1 & 30 & 100 & 2 & & Ref. 21 \\
\hline & India & 0.258 & 7.22 & 42.31 & 0.41 & 1.82 & Ref. 12 \\
\hline & Thailand & 0.28 & 5.6 & 16.2 & 0.18 & & Ref. 40 \\
\hline & Australia & 0.2 & 2 & 27.7 & 0.8 & & Ref. 41 \\
\hline & Australia & 2.09 & 0.73 & 42.7 & & & Ref. 17 \\
\hline & Malaysia & & & & & $0.24-0.41$ & Ref. 42 \\
\hline & North America & & & & & $0.1-9.6$ & Ref. 43 \\
\hline & Malaysia & 0.82 & 3.39 & 51.63 & 0.97 & 0.80 & Present study \\
\hline
\end{tabular}

for incorporation into the respiratory pigment haemocyanin, a copper-based pigment found in the blood of many species of molluscs and crustaceans ${ }^{46}$. The fish had comparatively lower mean-copper concentration than the invertebrates. Copper concentration may be regulated in fish due to the essential nature of this metal for metabolic process 47 .

No significant difference was observed between A. maculatus and P. merguiensis $(t$ (73.87) $=1.0, p=$ 0.32 ) in the case of zinc concentration. Whereas there was a significant difference between $A$. maculatus and A. $\operatorname{granosa}(t(46.51)=6.91, p=0.00)$, as well as between $P$. merguiensis and $A$. granosa $(t(56.23)=$ 9.27, $p=0.00)$. A. granosa had a zinc concentration of $93 \pm 13 \mu \mathrm{g} / \mathrm{g}$ dry wt, which was higher than that found in A. maculatus $(70 \pm 20 \mu \mathrm{g} / \mathrm{g}$ dry wt) and P. merguiensis $(76 \pm 10 \mu \mathrm{g} / \mathrm{g}$ dry wt). Barwick and Maher ${ }^{45}$ also found a lower concentration of zinc in fish. Moreover, Eisler et $\mathrm{al}^{48}$ described that the filter feeding bivalve molluscs generally show the highest accumulation level of zinc from marine environment. Zinc concentration in fish is comparatively higher than other reported values but within the range of values in the case reported for Malaysia. However, this value is lower than the safety levels (Table 2). For crustaceans, comparatively higher value was observed in the case of Malaysia but it is still lower than the safety guideline. On the other hand, in the case of molluscs, the measured value was higher than the other reported values but lower than the safety limit, 

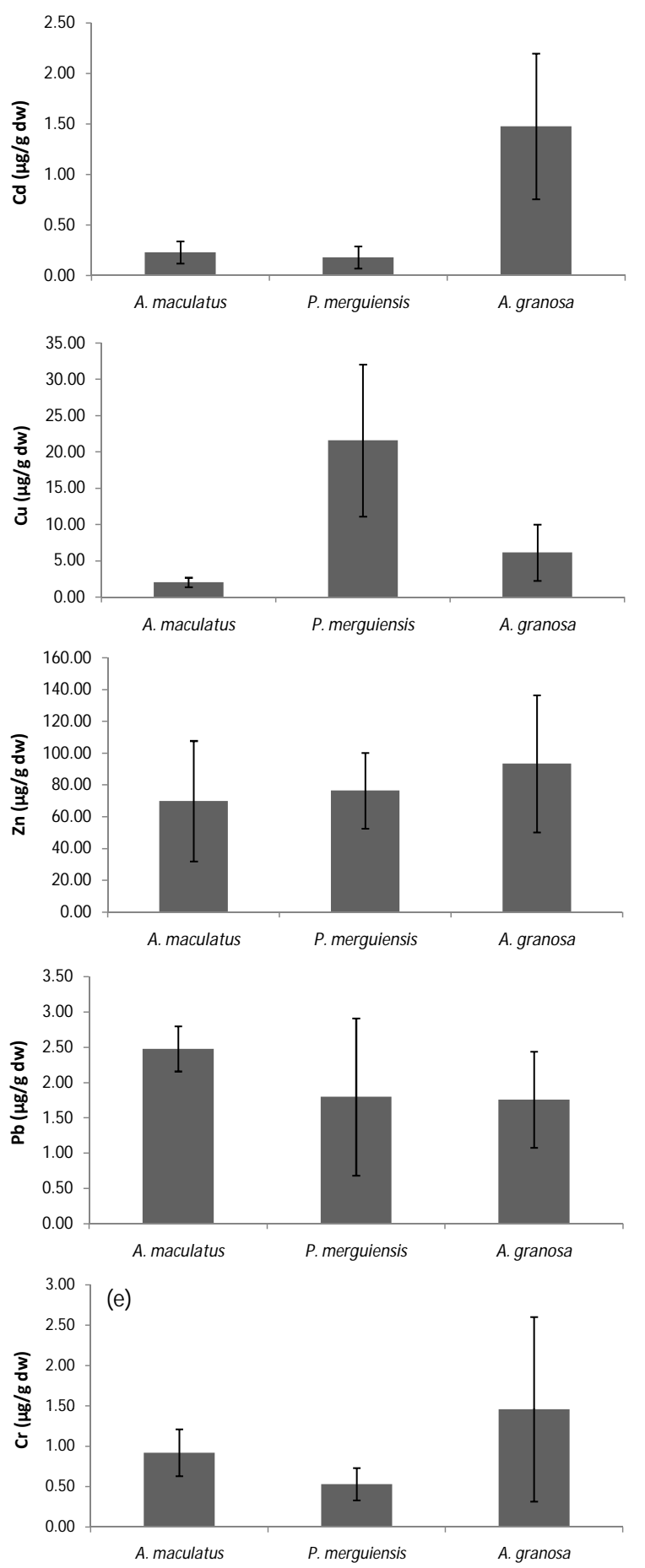

Fig. 2 Mean concentration of cadmium, copper, zinc, lead, and chromium in analysed marine organisms.

which is stated for the Malaysian population. Thus zinc consumption from organisms from Kapar coastal area poses no threat to humans.
This study found that $A$. granosa had a statistically significant lower lead value $(1.76 \pm 0.62 \mu \mathrm{g} / \mathrm{g}$ dry wt) than that of A. maculatus $(2.47 \pm 0.16 \mu \mathrm{g} / \mathrm{g}$ dry wt; $t(82.31)=5.62, p=0.00)$. There was a significant difference between $A$. maculatus and P. merguiensis $(t(59.22)=3.40, p=0.00)$. However, no significant difference was found in the case of P. merguiensis and A. granosa $(t(68.61)=0.19$, $p=0.84)$. The higher concentration of lead in fish is probably because of the food source. Comparatively lower lead concentrations were observed by Barwick and Maher ${ }^{45}$, which supports the present study. These lower concentrations in molluscs and crustaceans, are thought to be due to the partitioning of lead to shells and exoskeleton, as lead has been shown to accumulate via the same process as calcium ${ }^{49}$. In the case of fish and crustaceans, the lead concentrations are higher compared to other reported values, except for the value reported in Malaysia (Table 2). However, these values are lower than the safety limits. On the other hand, the measured value for molluscs in the present study demonstrated higher values than the literature but the value did not cross the limit of safety which has been declared for the Malaysian population. However, all organisms analysed have lead concentrations below the maximum permitted lead concentration for human consumption $(2.5 \mu \mathrm{g} / \mathrm{g}$ dry $w t)^{50}$.

The filter feeding species, A. granosa, had the highest concentration of chromium $(1.5 \pm 1.1 \mu \mathrm{g} / \mathrm{g}$ dry wt) followed by the $A$. maculatus $(0.79 \pm 0.27 \mu \mathrm{g} / \mathrm{g}$ dry wt), and $P$. merguiensis $(0.53 \pm 0.04 \mu \mathrm{g} / \mathrm{g}$ dry wt). An independent sample $t$-test revealed significant differences between $A$. maculatus and $P$. merguiensis $(t(77.76)=7.32, p=0.00)$, between A. maculatus and $A$. granosa $(t(50.23)=3.13, p=0.00)$, and P. merguiensis and A. granosa $(t(46.92)=5.52$, $p=0.00$ ). The chromium concentration observed in fish is within the range of other reported values but lower than the reported guideline (Table 2). There are very limited studies about the concentration of chromium in crustaceans. However, the value in this study is lower than the value reported in India. On the other hand, the chromium concentration in molluscs is also within the range of other places. Although there is no deleterious health effect from molluscs, the biologically available $\mathrm{Cr}$ (VI) is known to be carcinogenic to man and other species ${ }^{51}$.

The hierarchical cluster analysis and biotasediment accumulation (BSAF) factor were used to classify the analysed species in different groups. Hierarchical cluster analysis is a procedure which attempts to identify relatively homogeneous groups of cases 


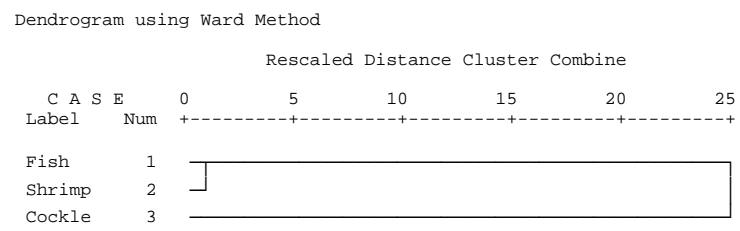

Fig. 3 Dendrogram for hierarchical cluster analysis of the three marine species based on the concentration of heavy metals during different sampling periods.

or variables based on selected characteristics. Fig. 3 shows the dendrogram derived by the ward method of the three species analysed in this study based on heavy metal accumulation. Results of the cluster analysis revealed two groups. The first group includes fish (A. maculatus) and shrimps (P. merguiensis), while the second group included cockles (A. granosa). Generally, the major differences are in the clustering of cockles and another two species, whereas the major similarities (the minimum distance) can be observed between fish and shrimp. Finally, the two groups are merged into a single cluster at the distance of 0.2 . The differences in between the analysed species in the case of heavy metal accumulation may have occurred from species-specific feeding habits such as uptake of food which plays an important role ${ }^{52}$.

The BSAF is a parameter which describes the accumulation of sediment-associated organic compounds or metals into tissues of ecological receptors. In this study, the efficiency of metal bioaccumulation in three types of marine organisms was evaluated by calculating the BSAF, which is defined as the ratio between the metal concentration in organisms and that in the sediment. The mean concentrations of $\mathrm{Cd}, \mathrm{Cu}, \mathrm{Zn}, \mathrm{Pb}$, and $\mathrm{Cr}$ in sediment collected during the three sampling periods from the different stations of the study area have been calculated as $0.29 \pm 0.02,9.34 \pm 0.12,118.6 \pm 1.0,35.21 \pm 0.18$, and $14.07 \pm 0.09 \mu \mathrm{g} / \mathrm{g}$, respectively. On the basis of the calculated BSAF, the A. maculatus was ranked in the following order, $\mathrm{Cd}>\mathrm{Zn}>\mathrm{Cu}>\mathrm{Pb}>$ $\mathrm{Cr}$ (Fig. 4). None of the studied metals were bioconcentrated in the tissues of $A$. maculatus to the levels higher than those in sediments, hence the BSAF were less unified. These findings suggest that the levels of contamination of these metals in Kapar coastal area do not exceed the fish capacity to regulate them. On the other hand, the trend of BSAF in P. merguiensis was $\mathrm{Cu}>\mathrm{Zn}>\mathrm{Cd}>\mathrm{Pb}>\mathrm{Cr}$. The mean concentrations of heavy metals in this species were generally lower than the sediment, except $\mathrm{Cu}$,

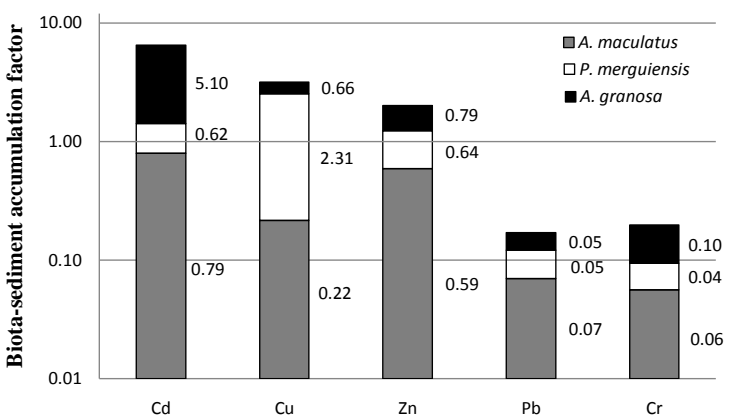

Fig. 4 The pattern of BSAF in analysed marine species collected from Kapar coastal area.

which indicates that this metal is readily accumulated in P. merguiensis. In the case of A. granosa, the pattern of BSAF is $\mathrm{Cd}>\mathrm{Zn}>\mathrm{Cu}>\mathrm{Cr}>\mathrm{Pb}$. The calculated value of BSAF for $\mathrm{Cd}$ is much higher than 1, suggesting a higher rate of $\mathrm{Cd}$ accumulation in this species. In this case, water probably acts as an additional source of $\mathrm{Cd}$ in A. granosa. Moreover, as $\mathrm{Cd}$ is known to be mobile in soils ${ }^{53}$, thus the $A$. granosa is more likely to accumulate higher concentrations of $\mathrm{Cd}$ relative to the sediment. Cheggour et $\mathrm{al}^{54}$ also calculated higher BSAF values for Cd in cockle tissue. Moreover, Bryan and Langston ${ }^{55}$ have suggested that Cd was solubilized from the sediment, rather than the solid-phase itself, and could be the main source of $\mathrm{Cd}$ to a number of benthic organisms. The BSAF values for other metals in A. granosa were lower than the unity. Accumulation factors were also reported to be around unity or below, generally, in soft tissues of the mussel Mytella strigata from a mangrove area of the northwest coast of Mexico ${ }^{56}$.

However, Adjei-Boateng et $\mathrm{al}^{57}$ stated that the relationship between the concentration of metal in the clam tissues and the sediment was not distinct. This study also failed to find any stable pattern of metal bioaccumulation between the three species analysed species, which supports the fact that the several variables control both bioavailability and accumulation of heavy metals in individuals exposed to contamination. Based on the values calculated, the different species of marine organisms could be classified into a few groups such as macro concentrator (BSAF $>2$ ), micro concentrator $(1<$ BSAF $<2)$ or deconcentrator $(B S A F<1)$ as proposed by Dallinger ${ }^{58}$. Therefore, based on that proposal, A. maculatus (mean BSAF 0.34 ) and P. merguiensis (mean BSAF 0.73) could be classified as a deconcentrator while the A. granosa (mean BSAF 1.34) follows the group of micro con- 
centrator. Therefore, among the species analysed in this study, A. granosa possesses a greater capacity for metal bioaccumulation than A. maculatus and P. merguiensis. This finding suggests that $A$. granosa is a potential indicator for pollution in a marine environment. In a previous study, it was found that molluses have the potential to be used as bio-indicators for the contamination of $\mathrm{Cd}$ and $\mathrm{Zn}$ in water and sediment of an estuarine environment ${ }^{14}$ and it was proposed as a simple model for predicting the bioaccumulation of sediment-associated natural organic contaminants by in faunal invertebrates ${ }^{59-61}$. Heavy metal BSAF in Perna viridis reflects the degree of industrialization and population density in coastal areas of Hong Kong ${ }^{62}$. Similarly, the bivalve possessed high BSAF for heavy metals mainly due to the wastewater and waste-residue drainage from the industries nearby ${ }^{4}$. Although several studies on molluscs associated with heavy metal pollution have been done, few studies reports the BSAF values. Therefore, the findings of the present study are quite significant from the environmental pollution viewpoint.

\section{CONCLUSIONS}

The higher metal concentration observed in A. granosa is due to their mode of life and feeding habit. Similarly, the calculated values of BSAF and MPI were also higher in the case of A. granosa. Therefore, it is suggested that these species are used as a bioindicator of marine pollution. Moreover, the heavy metal concentrations in the analysed samples were well within the approved limits set by the guidelines. As a result, it can be assumed that the seafood from this region is safe for human consumption.

Acknowledgements: The authors would like to thank all the members of Kapar Energy Ventures Sdn. Bhd. and laboratory members of chemical oceanography laboratory, University Kebangsaan Malaysia for their support during sampling and sample analysis. Appreciation also goes to the grants NOD/R\&D/02/00 and UKM-DLP-2011-083 for financial support.

\section{REFERENCES}

1. Fulekar MH, Dave JM (1986) Disposal of flyashan environmental problem. Int J Environ Stud 26, 191-215.

2. Tariq J, Jaffar M, Ashraf M, Moazzam M (1993) Heavy metal concentrations in fish, shrimp, seaweed, sediment, and water from the Arabian Sea, Pakistan. Mar Pollut Bull 26, 644-7.

3. Kalay M, Aly O, Canil M (1999) Heavy metal concentrations in fish tissues from the northeast mediterranean sea. Bull Environ Contam Toxicol 63, 673-81.
4. Rose J, Hutcheson MS, West CR, Pancorbo O (1999) Fish mercury distribution in Massachusetts, USA Lakes. Environ Toxicol Chem 18, 1370-9.

5. Hopkins WA, Congdon J, Ray JK (2000) Incidence and impact of axial malformations in larval bullfrogs (Rana catesbeiana) developing in sites polluted by coal-burning power plant. Environ Toxicol Chem 19, 862-8.

6. Dural M, Göksu MZL, Özak AA (2007) Investigation of heavy metal levels in economically important fish species captured from the Tuzla lagoon. Food Chem 102, 415-21.

7. Teodorovic N, Djukic S, Maletin B, Miljanovic Jugovac N (2000) Metal pollution index: proposal for freshwater monitoring based on trace metal accumulation in fish. Tiscia 32, 55-60.

8. Sharif R, Ghazali AR, Rajab NF, Haron H, Osman F (2008) Toxicological evaluation of some Malaysian locally processed raw food products. Food Chem Toxicol 46, 368-74.

9. Vijayram K, Geraldine P (1996) Are the heavy metals cadmium and zinc regulated in freshwater prawns? Ecotoxicol Environ Saf 34, 180-3.

10. Wu JP, Chen H-C (2004) Effects of cadmium and zinc on oxygen consumption, ammonium excretion, and osmoregulation of white shrimp (Litopenaeus vannamei). Chemosphere 57, 1591-8.

11. Yilmaz F, Özdemir N, Demirak A, Tuna AL (2007) Heavy metal levels in two fish species Leuciscus cephalus and Lepomis gibbosus. Food Chem 100, 830-5.

12. Sivaperumal P, Sankar TV, Viswanathan Nair PG (2007) Heavy metal concentrations in fish, shellfish and fish products from internal markets of India vis-a-vis international standards. Food Chem 102, 612-20.

13. Darracot A, Watling H (1975) The use of molluscs to monitor cadmium levels in estuaries and coastal marine environments. Trans Roy Soc $S$ Af 41, 325-38.

14. Abdullah MH, Sidi J, Aris AZ (2007) Heavy Metals $(\mathrm{Cd}, \mathrm{Cu}, \mathrm{Cr}, \mathrm{Pb}$ and $\mathrm{Zn})$ in Meretrix meretrix roding, water and sediments from estuaries in Sabah, North Borneo. Int J Environ Sci Educ 2, 69-74.

15. Batvari B, Kamala-Kannan S, Shanthi K, Krishnamoorthy R, Lee K, and Jayaprakash M (2008) Heavy metals in two fish species (Carangoidel malabaricus and $\mathrm{Be}$ lone stronglurus) from Pulicat Lake, North of Chennai, Southeast Coast of India. Environ Monit Assess 145, 167-75.

16. Thomann RV, Mahony JD, Mueller R (1995) Steadystate model of biota sediment accumulation factor for metals in two marine bivalves. Environ Toxicol Chem 14, 1989-98.

17. Phillips DJH (1976) The common mussel Mytilus edulis as an indicator of pollution by zinc, cadmium, lead and copper. II. Relationship of metals in the mussel to those discharged by industry. Mar Biol 38, 71-80.

18. Waquar A (2006) Levels of selected heavy metals in 
tuna fish. Arab J Sci Eng 31, 89-92.

19. Broek van den JL, Gledhill KS, Morgan DG (2002) Heavy metal concentrations in the Mosquito Fish, Gambusia holbrooki, in the manly lagoon catchment. In: UTS Freshwater Ecology Report. Department of Environmental Sciences, Univ of Technology: Sydney.

20. WHO (1989) Heavy Metals-Environmental Aspects. Environment Health Criteria. World Health Organization: Geneva, Switzerland.

21. MDC (1983) Malaysian Food Act. MDC: Malaysia.

22. Pourang N, Dennis JH (2005) Distribution of trace elements in tissues of two shrimp species from the Persian Gulf and roles of metallothionein in their redistribution. Environ Int 31, 325-41.

23. Onsanit S, Ke C, Wang X, Wang K-J, Wang W-X (2010) Trace elements in two marine fish cultured in fish cages in Fujian province, China. Environ Pollut 158, 1334-42.

24. Madany IM, Wahab AAA, Al-Alawi Z (1995) Trace metals concentrations in marine organisms from the coastal areas of Bahrain, Arabian Gulf. Water Air Soil Pollut 91, 233-48.

25. Ozretic B, Krajnovic-Ozretic M, Santin J, Medjugorac B, Kras M (1990) As, Cd, Pb, and $\mathrm{Hg}$ in benthic animals from the Kvarner-Rijeka Bay region, Yugoslavia. Mar Pollut Bull 21, 595-8.

26. Plotitsyna NF, Kireeva LI (1995) Contaminations in marine organisms from the Barents Sea (in Russian). In: Material on PINRO research. Polar Research Institute of Marine Fisheries and Oceanography (PINRO): Murmansk, Russia, pp 168-91.

27. Mishra S, Bhalke S, Saradhi IV, Suseela B, Tripathi RM, Pandit GG, Puranik VD (2007) Trace metals and organometals in selected marine species and preliminary risk assessment to human beings in Thane Creek area, Mumbai. Chemosphere 69, 972-8.

28. Fidan A, Ciğerci İ, Konuk M, Küçükkurt İ, Aslan R, Dündar Y (2008) Determination of some heavy metal levels and oxidative status in Carassius carassius L., 1758 from Eber Lake. Environ Monit Assess 147, $35-41$.

29. Chi Q, Zhu G, Langdon A (2007) Bioaccumulation of heavy metals in fishes from Taihu Lake, China. J Environ Sci 19, 1500-4.

30. Ahmad AK, Othman MS (2010) Heavy metal concentration in sediment and fishes from Lake Chini, Pahang, Malaysia. J Biol Sci 10, 93-100.

31. Yap CK, Ismail A, Chiu PK (2005) Concentrations of $\mathrm{Cd}, \mathrm{Cu}$ and $\mathrm{Zn}$ in the fish Tilipia, Oreochromis mossambicus caught from Kelana Jaya pond. Asian $J$ Water Environ Pollut 2, 65-70.

32. Irwandi J, Farida O (2009) Mineral and heavy metal contents of marine fin fish in Langkawi Island, Malaysia. Int Food Res J 16, 105-12.

33. Biney CA, Ameyibor E (1992) Trace metal concentrations in the pink shrimp Penaeus notialis from the coast of Ghana. Water Air Soil Pollut 63, 273-9.
34. Ba D (1988) Analyse de contaminats chez les organisms marins d'importance commercial dans les eaux cotieres du Senegal. Rapport Atelier WACAF/2 Accra: Ghana.

35. Metongo B (1988) Metaux lourds des organisms marins cote d'Ivoire. Rapport Atelier WACAF/2, Accra: Ghana.

36. Mbome L (1988) Heavy metals in marine organisms from Cameroon. WACAF/2 Workshop Raport, Accra, Ghana.

37. Awaluddin A, Mokhtar M, Sharif S (1992) Accumulation of heavy metals in tiger prawns (Penaeus monodon). Sains Malaysiana 21, 103-20.

38. Patimah I, Dainal AT (1993) Accumulation of heavy metals in Penaeus monodon in Malaysia. In: International Conference on Fisheries and the Environment. Beyond 2000. UPM, Serdang, Malaysia.

39. Ismail A (1993) Heavy metal concentrations in sediments off Bintulu, Malaysia. Mar Pollut Bull 26, 706-7.

40. Huschenbeth E, Harms U (1975) On the accumulation of organochlorine pesticides, PCB and certain heavy metals in fish and shellfish from Thai coastal and inland waters. Arch Fischereiwiss 25, 109-22.

41. Mackay NJ, Williams RJ, Kacprzac JL, Kazacos MN, Collins AJ, Auty EH (1975) Heavy metals in cultivated oysters (Crassostrea commercialis $=$ Saccostrea cucullata) from the estuaries of New South Wales. Aust J Mar Freshwat Res 26, 31-46.

42. Mat I (1994) Arsenic and trace metals in commercially important bivalves, Anadara gradosa and Paphia undulata. Bull Environ Contam Toxicol 52, 833-9.

43. Hall AR, Zook EG, Meaburn GM (1978) National Marine Fisheries Service Survey oftrace elements in the fishery resources. In: US Dep Commerce NOAA Tech. Rept. US Dep Commerce.

44. NAS-NRC (1982) National Academy of SciencesNational Research Council. Drinking Water and Health. Vol. 4. Washington DC: National Academic Press.

45. Barwick M, Maher W (2003) Biotransference and biomagnification of selenium copper, cadmium, zinc, arsenic and lead in a temperate seagrass ecosystem from Lake Macquarie Estuary, NSW, Australia. Mar Environ Res 56, 471-502.

46. Clarke RB (1986) Marine Pollution. Oxford, New York: Clarendon Press.

47. Denton GRW, Burdon-Jones C (1986) Environmental effects on toxicity of heavy metals to two species of tropical marine fish from Northern Australia. Chem Ecol 2, 233-49.

48. Eisler R, Barry MM, Lapan RL, Telek G, Davey EW, Soper AE (1978) Metal survey of the marine clam Pitar morrhuana collected near a Rhode Island (USA) electroplating plant. Mar Biol 45, 311-7.

49. Sorensen EM (1991) Cadmium. In: Metal Poisoning in Fish. CRC Press, Florida, pp 175-234. 
50. ANFA (1992) Australian Food Standards Code. Australia New Zealand Food Authority.

51. Phillips DJH, Thompson GB, Gabuji KM, Ho CT (1982) Trace metals of toxicological significance to man in Hong Kong seafood. Environ Pollut B Chem Phys 3, 27-45.

52. Coetzee L, du Preez HH, van Vuren JHJ (2002) Metal concentrations in Clarias gariepinus and Labeo umbratus from the Olifants and Klein Olifants River, Mpumalanga, South Africa: Zinc, copper, manganese, lead, chromium, nickel, aluminium and iron. Water $S A$ 28, 433-48.

53. Alloway BJ (1990) Cadmium. In: Alloway BJ, ed Heavy Metals in Soils. Blackie and Son Ltd: New York. pp 100-24.

54. Cheggour M, Chafik A, Langston WJ, Burt GR, Benbrahim S, Texier H (2001) Metals in sediments and the edible cockle Cerastoderma edule from two Moroccan Atlantic lagoons: Moulay Bou Selham and Sidi Moussa. Environ Pollut 115, 149-60.

55. Bryan GW, Langston WJ (1992) Bioavailability, accumulation and effects of heavy metals in sediments with special reference to United Kingdom estuaries: a review. Environ Pollut 76, 89-131.

56. Szefer P, Geldon J, Ali AA, Osuna FP, Ruiz-Fernandes AC, Galvan SRG (1998) Distribution and association of trace metals in soft tissue and byssus of Mytella strigata and other benthal organisms from Mazatlan Harbour, Mangrove Lagoon of the northwest coast of Mexico. Environ Int 24, 359-74.

57. Adjei-Boateng D, Obirikorang KA, Amisah S (2010) Bioaccumulation of heavy metals in the tissue of the clam Galatea paradoxa and sediments from the Volta Estuary, Ghana. Int J Environ Res 4, 533-40.

58. Dallinger R (1993) In ecotoxicology of metals in invertebrates. In: Strategies of Metal Detoxification in Terrestrial Invertebrates. Lewis Publisher, Boca Raton, FL, pp 246-332.

59. Di Toro DM, Zarba CS, Hansen DJ, Berry WJ, Swartz RC, Cowan CE, Pavlou SP, Allen HE, Thomas NA, Paquin PR (1991) Technical basis for establishing sediment quality criteria for nonionic organic chemicals using equilibrium partitioning. Environ Toxicol Chem 10, 1541-83.

60. Boese BL, Lee Ii H, Specht DT, Randall R, Pelletier J (1996) Evaluation of PCB and hexachlorobenzene biota-sediment accumulation factors based on ingested sediment in a deposit-feeding clam. Environ Toxicol Chem 15, 1584-9.

61. Kannan K (1999) Clam-sediment accumulation factors for polychlorinated biphenyl congeners at a contaminated estuarine marsh. Toxicol Environ Chem 68, 159-67.

62. Blackmore G (1998) An overview of trace metal pollution in the coastal waters of Hong Kong. Sci Total Environ 214, 21-48. 